\title{
The Moral Irrelevance of Autonomy
}

\author{
Gary Comstock \\ lowa State University
}

Editors' Note: The following papers on "Autonomy and the Moral Status of Animals" are from symposia on that subject which were presented at the Pacific Division meetings of the Society for the Study of Ethics and Animals, held in Los Angeles, California, in March, 1990, and at the Conference on "Animal Rights and our Human Relationship to the Biosphere," held at San Francisco State University, in April, 1990.

\section{Q QQQQQQQ \&QQ QQQ}

Once upon a time a boy and his gang drew a big circle around themselves and defied anyone else to get in it. A clever fellow, the leader drew the line just large enough to include all those like him but just small enough to exclude everybody else. The outsiders initially paid little attention to the rascals, letting them have their fun. But before long, the boys' temper had worsened considerably, and soon everyone on the beach was sitting up. What they saw was not pretty: the boys grimly ordering everyone else about and slowly kindling a bonfire in their barbecue pit.

The outsiders' responses varied. Some tried discreetly to step over the line, pretending they had been in all along. (This strategy met with mixed success, depending upon how much the marginal types already resembled the fellows.) Others tried various forms of surreptitious gerrymandering, furtively attaching a little blip here, an appendix there, so as to include them and theirs in the circle. (This ploy almost always failed, the eagle-eyed gang being obsessed with its borders.) In general, outsiders stayed outsiders.

But the boys had a problem of their own: They could not uniformly agree about who was in and who was out. So just when things seemed to be turning most

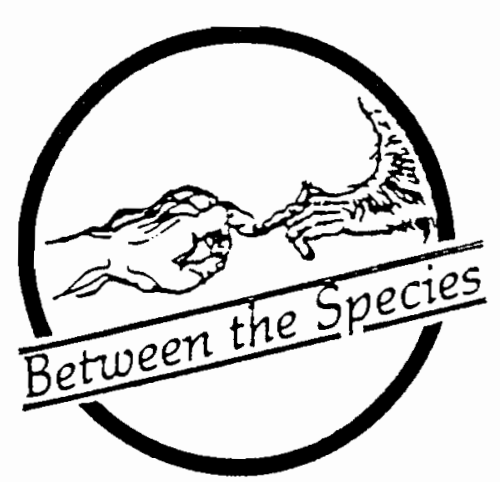

ugly, the whole menace collapsed from within. One of the boys grabbed the leader's stick and drew a tighter, more conservative, line inside the first one. Then another seized it and reduced the circumference even more. The boys came to words, and then to pointing and shoving. Which one of these lines was the real one? What kind of line is it that lets him in?

The internal feuding spelled the end of the boys' frightening game because you cannot keep people out if you do not know who is in. But it had another unexpected effect. As the insiders separated into warring factions, the outsiders drew strangely together, for the demise of the boys' party opened up a vast new range of activities on the beach. Before long there was all sorts of merry-making: swimming, sunbathing, castle making, dog walking, windsurfing, ice cream eating, kite flying. They all found something they liked doing, and even the boys began to drop their sticks, leave off their fuming, and join the fun.

The moral of the story is this: The end of linedrawing means the beginning of cooperative life.

In previous work, R. G. Frey has argued that the possession of "moral rights" is not the line separating us from nonhuman animals. His reason is not that some animals are inside this line (he denies that any

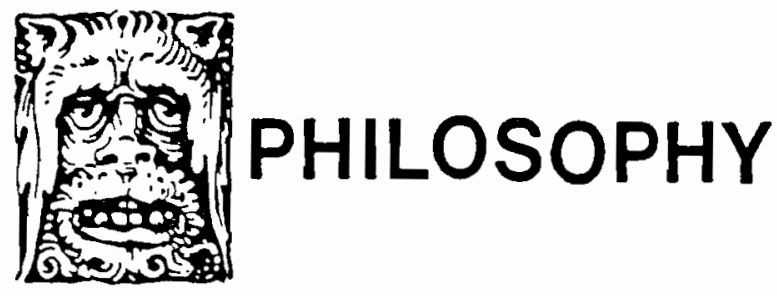


are), nor that some humans are outside it (he affirms that many are), but rather that the line itself is too fuzzy. ${ }^{1}$ Talk about moral rights, Frey explains, is unsupported by good arguments and is more successful as rhetoric than as philosophy. ${ }^{2}$ Frey is a utilitarian who puts little stock in general in the Kantian picture of morality, and so he rejects the "moral rights" line.

He does not reject line-drawing. In a recent article, "Autonomy and the Value of Animal Life," he lays down what he believes is a clearer boundary than any other current candidate: autonomy. ${ }^{3}$ According to Frey, nonhumans lack moral standing not because they lack what no one probably possesses (rights) but, rather, because they lack what all "normal adult humans" possess: autonomy, the ability to control or make something out of our lives. ${ }^{4}$

Why should Frey want to shift the burden of the case against animals onto the back of a concept traditionally associated in the most intimate way with that of moral rights? Because he finds it a far less ambiguous notion, not to mention a less controversial one. In the first sentence of the article he claims that autonomy has had "great stress" placed upon it: "in Anglo-American society, [by] virtually every moral theory of any note." 5 Because it has received such stress by so many other theorists dealing with so many other kinds of ethical issues, he believes that it may serve as the limiting concept for all inquiries into our moral duties toward animals.

Frey is not alone in focusing attention on this line. One of the best known cases for the moral standing of animals-_Tom Regan's case_puts as much weight on autonomy as Frey's case against animals. Regan's strategy if to try to attach a large bubble to Frey's circle so as to make insiders not only of homo sapiens but of all adult higher mammals. Thus, Regan makes each of the following claims: Many animals "have preferences and have the ability to initiate action with a view to satisfying them;" this constitutes "preference autonomy;" and many animals, possessing such autonomy, must therefore be granted moral considerability. ${ }^{6}$ Regan does not agree with Frey as to where the line should be drawn, but he does agree that autonomy is the border.

This is not the way for defenders of animals to deal with line-drawers. As Frey correctly suggests, Regan's tack only underscores the importance of the line, contributing that much more heat to the debate about where the line"really" is. The better strategy is to keep one's distance, sneaking into the midst of the fray from time to time to keep everyone honest, but never committing oneself to its ultimate importance. The boys should constantly be reminded about that line previously drawn there, this one so recently and confidently drawn here. This tactic will never defeat the boys directly, but it will buy valuable time. The idea is so to pester all line-drawers with the knowledge of their own ineptness that they will eventually get frustrated and abandon the enterprise of their own free will.

Far from helping Regan to help Frey set a new line in concrete, I want to sneak in, give their disputed border a good scuffling with my feet, and get out. My intent is to show that autonomy is virtually useless as a line to tell us which beings have and which beings do not have moral standing. My thesis is that we must not trust autonomy to describe the circle outside of which are individuals whom "the way is ... open" to killing and eating. I should tell you at the start that I do believe with Frey that animals are not autonomous. But I also believe with Regan and others that we should not kill them and eat them or use more of them in scientific experiments. How can I believe both? Because precious little follows for practical morality from the fact that animals lack the ability to plan or control their lives.

Frey's definition of autonomy is more precise than Regan's "preference autonomy." It has three elements, the first of which is the freedom to act on our own behalf. Autonomy is "our desire to achieve things for ourselves," to make "something of our lives," the way a fledgling philosopher might want to succeed on her own rather than trying to ride on her famous husband's coattails. To illustrate the point Frey tells of an academic acquaintance who was concerned that his untenured wife might not be promoted. The husband suggested that he write some publishable papers which she could take and revise and then submit to journals as her own. The woman was rightly insulted by the idea because she did not want to make something of herself by deceitfully using her husband's work. She wanted to make something of herself by relying on her own talents and powers She wanted to make something of herself. By rebuffing her husband's attempt to intrude, the woman showed that she was not subject to control by paternalistic outside forces. She was free "of the coercive interference of others." 8

The second requirement is freedom from internal coercion. In order to pursue the ends we most cherish, we must not only gain independence from the desires of outsiders, but we must also master our own desires as well. "A certain ordering" of life is necessary if an 
untenured professor is to "put herself in a position to be able to produce serious academic work." If she does not control her minor impulses, she will be pulled in so many directions that she will not be able to devote herself to the desire she desires most. Self-government means that we are able to forego certain lower-order preferences (e.g., playing in a semi-pro basketball league) in order to pursue higher-order desires (e.g., making associate professor). Freyan autonomy requires "internal" as well as "external" freedom, the ability to make higher-order decisions about the relative importance of lower-order desires.

The third requirement is to decide for oneself about the kind of life one wants to lead. The professor who successfully resists the intrusions of her husband and who successfully controls her less desirable desires may still be doing something she has not chosen. Suppose that she is working to be associate professor for no other reason than than her mother was a professor before her and her grandmother before that and she feels, for religious reasons drummed into her as a child, that she ought to do what her family wants. Frey would not call this woman autonomous, because she is not pursuing a career she has chosen for herself. She is pursuing a plan of life that has been imposed upon her. Notice that she has all of the equipment needed to survey a range of possible plans and to select one for herself but simply has not used it. Instead, she has settled for doing the best she can in what she considers "the family's" line of work. Freyan autonomy requires that we think rationally about the variety of conceptions of the good life, deliberately choose one, and consistently pursue it.

Frey calls his version of the line "autonomy as control." Being in control is important for Frey, as his example of a nonautonomous person shows. Imagine a successful businessman who longs to be a painter and yet continues to spend his energies perfecting his father's business. Frey's opinion of such a man is harsh, and he thinks many of us will "doubtless" be struck by how "weak" the man is. Frey puts the matter straightforwardly: "The real charge against this man is servility; he has allowed, for whatever reason, others to impose their conception of the good life upon him." 0 Here we see how much weight Frey attaches to the third requirement. You are not autonomous: if you have not selected a plan of life from a range of options, if you have not made up your mind about what you think the good life is, and if you have not taken decisive action to pursue your conception of the good life.
Those who are not autonomous, Frey believes, are morally inferior to those who are autonomous. Denying that all humans have equal moral value, he asserts that the value of someone's life is directly related to its quality. ${ }^{11}$ Since he thinks that the quality of the moral life of a nonautonomous person is less than the quality: of an autonomous person, Frey must also think that we would all be better persons, morally speaking, if we seized control of our lives, took matters into our own hands, and changed careers to pursue the one we most desire.

Frey does not address himself to some of the knottier questions raised by his analysis. Is autonomy intrinsically good or good as a means to another end? Frey seems to think that it is good in itself. But can't we develop our autonomy at the expense of others? Couldn't we strive to become more autonomous in order better to exploit others sexually or coerce them into unearned business favors? Nor does Frey tell us what to think about moral theories in which autonomy has not been heavily accented. Such theories may not be part of something called "the" tradition of AngloAmerican moral theory, but they are undeniably part of the moral practices of Brits and Americans: the Land Ethic and environmentalisms; Natural Law, Divine Command, and other religiously based theories; feminist and pragmatist perspectives; all aretaic theories that insist on the multiplicity and irreconcilability of the virtues. These theories are not bit players in the actual moral lives of those living in Great Britain and the United States even if they have been largely ignored by most of their moral philosophers. But if few of the alternative theories stress autonomy, why should we think it "central" or noncontroversial?

Nor does Frey address in this article the most troubling question of all: Even if autonomy were demonstrated to be the line separating us from animals, would that justify killing and eating cows or cementing baboon heads into steel sleds and slamming them against walls? May we so treat any and every being that lacks autonomy?

However urgent these questions may be, they are not the ones Frey sets out to answer in the present essay, and I will not pursue them here. Rather, the central claim of his paper is that autonomy is a property of the "normal adult human" and a necessary feature of the good life. It is this claim I wish to contest. Frey could mean it in one of two ways. He could intend it as a descriptive claim, that all "normal adult humans" just are autonomous. This would be an empirical judgment 
about the kinds of lives led by most people in the world. If this were Frey's intent we would have to do some social-scientific work to find out whether he was right. Lacking the results of such a study and basing my response only on my own experience with what appear to be "normal adult humans," I must nevertheless say that I find this view fantastic. The majority of "normal adult humans" I know are far from autonomous in Frey's sense, and I shall shortly introduce you to one..$^{12}$

But Frey might intend his claim, on the other hand, as a normative judgment-that all normal adults should be autonomous. This is more properly a philosophical judgment, and one with which I disagree. I do not believe that autonomous people necessarily live lives of higher moral quality than less autonomous folk, and the person I will describe below will serve to show why I hold this view as well.

Assume that autonomy is, on the whole and all things considered, a good of one sort or another. In the absence of other considerations it is better to have control over your life than not to do; better to have a life plan than not to have one; better to be internally free than to be tied up by your lesser desires, better to be externally free than to be hamstrung by others' plans for you. ${ }^{13}$ Assume further that "the value of life is a function of its quality, its quality a function of its richness, and its richness a function of its scope or potentiality for enrichment."14 And assume too "that many humans lead lives of a very much lower quality than ordinary normal lives, lives which lack enrichment and where the potentialities for enrichment are severely truncated or absent." 15 From these premises it does not follow, as Frey seems to assume, that beings who are not fully autonomous are beings who either lack moral standing altogether or who would have a higher quality of life if they exercised more control over it.

To see the fallacy of the conclusion consider a normal adult human who lives a life of high moral quality but has never formulated a plan of life. Carrie is a forty-seven-year-old mother of six who not only can "read, do higher mathematics, build a bookcase, [and ] make baba ghanoush," but who also has served in a responsible position as secretary of an elementary school for twenty-five years. ${ }^{16}$ According to the school's principal, students refer to Carrie as "Mom" because she loves to serve as a surrogate parent to homesick, confused, and lost kindergartners. She is not hesitant to leave her typewriter to put her arm around a distraught five-year-old, taking her into the faculty lounge for a Kleenex and a doughnut. Graced with superior counselling skills, Carrie is an excellent conflict mediator who quietly but effectively intervenes between faculty and administrators, smoothing out school life in ways that are no less significant for being nigh imperceptible. Here is a moral exemplar who successfully raised her children and then turned her considerable nurturing skills to those with whom she comes in daily contact.

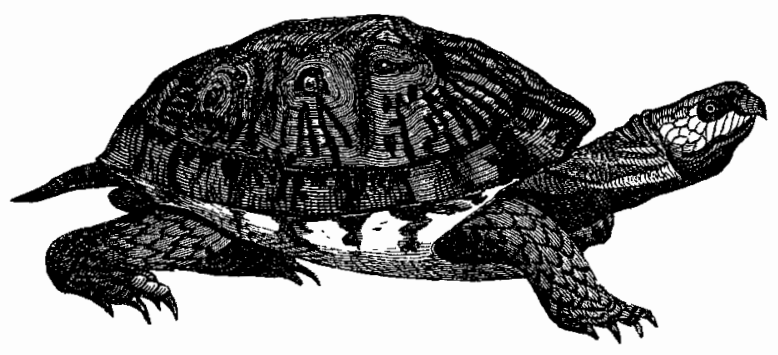

Carrie likes her job and is good at it. Over the years she has developed the skills of an administrative assistant and (while she is still paid secretarial wages) is indispensable to the operation of her institution. Carrie not only knows how to facilitate relationships between cranky teachers, but also how to teach them to load up Lotus and Word Perfect, how to enter, compose, and print the annual budget, and how to finesse travel reimbursements through the school district office for administrators who consistently forget their receipts.

But Carrie did not choose her career as a secretary, her career as a mother, or her self-sacrificial way of life. While she finds some measure of fulfillment in being a secretary, she would rather volunteer her time at the local hospital, perhaps even be a nurse, than continue to put up with the inevitable recurring conflicts at school. She hesitates to quit her job, however, because she fears leaving a position which offers her seniority, a measure of self-fulfillment, and reasonably happy working conditions. Moreover, she does not really know how she would go about "changing careers" at this point, and she believes (almost certainly in error) that her husband and middle-aged children are not in a 
position to afford her that luxury. Above all else, Carric wants her children to be happy and her husband satisfied. Her perception of their needs is more important to her than her other career desires.

Mothering is the activity that gives Carrie the most satisfaction. But is this a deliberately chosen higherorder preference? Surely it is for some women, but this does not seem to be the right way to describe Carrie. Carrie is a reflective and skilled person who has shaped the lives of others in profound ways. But, as she says herself, her satisfaction in mothering is more instinctual than chosen. Raised in a rural area by conservative Catholic parents, Carrie's mothering conception of a good life is more an inherited one than one she has deliberately chosen from a menu. She never remembers having thought about, much less deliberately chosen, a "plan" of life.

Not only does Carrie fail Frey's three-fold criterion for bcing in the autonomy circle, she does not even want to try to get in. Carrie has paid careful attention to the cultural conditions in which her children were raised, and she is not at all certain that she approves. She has known for a long time how strongly they were encouraged from kindergarten on to "find themselves," to exhibit independence of thought, to formulate a rational life plan, to seek equality with others, to pursuc their own happiness. Sometimes she finds this amusing, because when she was growing up, "you didn't have all this agonizing over who you were and where your 'relationships' were going-you just found a man, fell in love, and got married." But other times she is profoundly disturbed by it. She fears that her children have been coerced by their consumeristic culture into placing an overweening importance on their own successes, their own achievements. Being happy is their bottom line. When Carrie was growing up, that was not the bottom line; it was caring for others. By allowing her children to chase autonomy has she also let them lose sight of the value most cherished by her mother?

Sara Ruddick offers a perceptive comment that illuminates Carrie's concern. Ruddick's observation also helps to explain why Carrie does not think she would necessarily be a better person if only she were more independent:

Because [mothers] live through and witness shifting power relations, because they watch firsthand the anxieties of children driven to be equal, mothers would be slow to wish upon themselves or anyone they care for the fearful pursuit of equality. In the maternal view of conflict, it is not necessary to be equal in order to resist violence. ${ }^{17}$

In Carrie's conception of the good life, resisting violence while nurturing peace is more important than resisting others while nurturing independence. Again, Ruddick helps us to understand the specificity of this kind of life: "The peacemaker asks of herself and those she cares for, not what they can afford to give up, but what they can give; not how they can be left alone, but what they can do together." 18

So that you do not misunderstand me, let me add immediately that Carrie is not the sort of "intensely sympathetic," "intensely charming," Victorian woman described by Virginia Woolf in Women and Writing:
She excelled in the difficult arts of family life. She sacrificed herself daily. If there was chicken, she took the leg, if there was a draught she sat in it-in short, she was so constituted that she never had a mind or wish of her own, but preferred to sympathise always with the minds and wishes of others." 19

Just as Woolf had to "kill" this "Angel in the House"-herself-before she could write, so Carrie had to kill the "Mother in the Home" before she could go out into the workplace with her youngest child still not in school. ${ }^{20}$ Carrie is not in the category of self-abasing religious housewives, nor even in the category Diana T. Meyers describes as "the traditional women." 21 She is a full moral agent with immense talents in the areas of care, compassion, hospitality, faimess, discernment, responsibility, loyalty, and love, She exhibits, in short, an extremely high quality of moral life. Notice that she is by no means a "less" rather than "more" normal human, much less a marginal one. We are not talking here about someone who has severe brain damage or is seriously mentally-enfeebled. We are not talking about a criminal, a ne'er-do-well, or even an apathetic, chocoholic soap opera addict. Carrie is as normal a human as you can find. If she has any distinction, it is only that she is such a good person. Nevertheless, she has not selected a plan of life from a range of options; she has not made up her own mind about what the good life is; and she has not taken decisive action to pursue her conception of the good life. 
Carrie is a reflective, nonautonomous, saint. She does not have control over her life and, moreover, she is incapable of exercising control over her life. And yet the quality of her life is extremely high. Here is a woman who falls outside of Frey's circle.

To get a clearer picture of the type of individual I have in mind, consider four different types of saints. ${ }^{22}$ A saint is anyone who lives a self-sacrificial life. A self-sacrificial life is one that consistently promotes the legitimate interests of others while occasionally acting contrary to legitimate interests of the self. Strongly autonomous saints act self-sacrificially because they want to act self-sacrificially. Mother Teresa of Calcutta not only has the ability to reflect critically on her desires but also the freedom of will to change her way of life if she decides, one morning, to leave the poor and get into advertising. Weakly autonomous saints act selfsacrificially because they want to act self-sacrificially. Unlike the strong autonomous saint who energetically affirms and reaffirms her way of life, however, this saint is attracted to other conceptions of the good life. She is unable to switch directions because she lacks the willpower to act on her other desires. She continues to act self-sacrificially, but this is as much because of weakness of will as anything else. Both of these saints fit Frey's depiction of what he calls normal adult humans. Both are autonomous. And the weakly autonomous saint would be better off if she were to take more control over her life.

Now consider two nonautonomous saints. The strongly nonautonomous saint acts wantonly in a selfsacrificial way. Like Felicité in Flaubert's short story, "Un Simple Coeur," this saint's operative desire is always to relieve the suffering of others, but the desire to relieve suffering is not a desire she has chosen. What is more, this is not a desire she could choose, because nature and nurture have conspired against her to produce a person who lacks freedom of will. In Harry Frankfurt's apt expression, she "neither has the [will she] wants nor has a will that differs from the will [she] wants." 23 Driven by psychological and sociological forces beyond her control, Felicité just happens to be a saint rather than a sinner.

Weakly nonautonomous saints, like strongly nonautonomous saints, do not have the power to choose their self-sacrificial way of life. Their operative desires are out of their control, determined by powerful forces of behavioral make-up, habit, and socialization. Unlike the strongly nonautonomous saint, however, this person is conscious of the forces shaping her and is capable of reflecting on her desires. She is sometimes disposed, like Carrie, to want a different way of life. Unfortunately, she lacks the willpower to act on these desires. Like the weakly autonomous saint, the weakly nonautonomous saint is not always happy with the fact that she is a saint instead of an advertising executive.

Carrie is a reflective, weakly nonautonomous, saint. Her will is not free. Yet she is a powerful woman, having shaped the lives of those around her in profound and lasting ways. Her children, her students, her husband, her brothers and sisters, her colleagues at work--all will tell you how dramatic Carrie's influence has been. Carrie may be nonautonomous, but she nevertheless exercises tremendous power over others, and she does it for their good.

I want to make it clear that when I deny that women like Felicité and Carrie have autonomy I am not denying that so-called "traditional" women have autonomy. As Meyers rightly points out, "the claim that feminine socialization al together excludes most women from the class of autonomous agents is both morally repugnant and factually unsubstantiated." 24 I am not claiming anything like the repugnant thesis that women are not autonomous. I am claiming only that some women, like some men, lack autonomy, and that lacking autonomy constitutes no reason to downgrade a person's value. The problem here is that we are trained to interpret "nonautonomy" as a negative judgment about someone's character when autonomy, in this context, should be a descriptive rather than a normative term. No one would accept a definition of autonomy according to which they did not qualify as autonomous. But if no one falls outside our definition, then the definition is useless. In calling a person nonautonomous, we must keep it firmly in mind that we intend, prima facie, no negative comment about that person.

So I repeat. Carrie is a weakly autonomous saint. But if Frey is right that the way is open to killing and eating nonautonomous beings, then we would be justified in killing and eating Carrie. But that is absurd.

Frey might try to save his thesis by denying one of three things about Carrie. He might try to deny that she is a normal adult human. By putting her in the class of severely brain-damaged infants-and cowshe could simply assert that I have not chosen a typical human being as my example. This response is very weak. If Carrie is not a normal adult human then I do 
not know one. We may safely assume that Frey will not try this route of escape.

More plausibly, Frey could try to deny that Carrie lives a life of high moral quality. ${ }^{25}$ Such an argument might go as follows. While Carrie has many wonderful qualities and is certainly a normal human, her life would nonetheless be better, morally speaking, if she were to exercise more of her autonomy. By leaving her secretarial job and becoming a nurse she could continue to exercise her mothering and nurturing skills but in an environment she had chosen herself. On this interpretation, Carrie would not qualify as a counterexample of Frey's view at all. Instead, she would serve to reinforce the importance of autonomy as a measure of morality, being one more example of the truth of the claim that a life with less autonomy is of lower quality than a life with more of it.

But this response begs the question. We could only determine that Carrie's life was inferior because it was nonautonomous if we already knew that a nonautonomous life was by definition inferior. Whether one can have a good life and be nonautonomous is precisely the question we have set out to answer, and we cannot answer it by repeating it as an assertion.

But there is another way that Frey could press the objection. He might begin by admitting that Carrie's life is a good one, and that she is not independent, but then go on to claim that her life would nevertheless be a better one if she were to become autonomous. This response is stronger, but it gives away the store by granting my central point: Nonautonomy is compatible with the good life. So if this is the escape route Frey chooses, I shall respond by putting the ball right back into his court, with some English on it: Nonautonomy is not only compatible with a high quality of moral life, but further, autonomy may in some instances diminish the quality of a person's life. How so?

Imagine another secretary, Molly, who is like Carrie in every respect except that Molly chose her job as a secretary. Twenty-five years ago Molly weighed the alternatives, decided on a life plan, ordered her life so as to become a secretary, and then conscientiously pursued her conception of the good life. Molly's quality of life, one can imagine Frey saying, is superior to Carrie's simply because Molly chose her line of work rather than having it foisted upon her.

Now, we already know Frey's complaint about Carrie. It is the same as his charge against the successful businessman: servility. Carrie has allowed others (her husband, her children, her religious relatives) to impose their conceptions of the good life upon her. She proceeds to live them out. To be sure, she is no slave, "but," as Frey says, "we can be servile without being a slave." Frey thinks that Carrie, for all of her good traits, should throw off these external bonds. She should become more Molly-like.

This is an interesting thought experiment, but it makes a couple of problematic assumptions. First, how free was Molly twenty-five years ago when she made her decision? One easily sees behind Molly's choice glossy magazine advertisements for Trend Business College, the happy voices of secretarial friends, 1950s movies about the glamor of big business. In the era of behavioristic psychology, we have leamed to distrust confident assertions such as "I and I alone have chosen this line of work over that one." We are sensitive after Freud to the power of subconscious forces on rational processes, and we no longer are certain that the quality of the lives of people who avow that they have chosen their conception of the good life is better than the quality of those people's lives who-perhaps more candidlyadmit that they probably have not chosen their conception of the good life. Self-deception is more likely to plague the person who imagines herself autonomous than the person who acknowledges that she is not. There are good reasons to think that Molly's allegedly autonomous choice was not autonomous at all.

Of course, if this Molly's choice was not autonomous, that Molly's choice could have been. So let us now consider the Molly who really was making the choice for herself. Couldn't Carrie be a better person by adopting more of this Molly's assertiveness and independence? No, for the following reason. Not all of the virtues are necessarily compatible with all of the others, and a high degree of personal autonomy and an intensely self-sacrificial spirit seem rarely to be found in the same character. To put the same point a different way, Carrie would no longer be Carrie if the author of her story were to give her a Mollyan life plan.

Frey might respond to this claim by denying that Carrie's character is so limited; he might even say that he knows a servant like Carrie with Molly's selfassertiveness. I would not believe him and would ask him to show us that person. "Showing" here means composing a coherent, realistic narrative about a dependent-Carrie who exercises Molly-like control. I would not deny that there is a possible world in which the Molly/Carrie in question might exist, and I can 
imagine a science fiction writer constructing a character who is simultaneously in control and out of control, other-directed and self-sacrificial while also selfdirected and self-interested. My point is not that the alleged character "Molly/Carrie" violates all laws of logic; it is that she violates our laws of psychology. I cannot envision Carrie as a character in a realistic novel exhibiting Molly's self-assertive individualism. Why? Because the literary demands of similitude require a considerable amount of consistency. In order to present Molly/Carrie convincingly, an author would at some point have to have Carrie sacrifice the beliefs, practices, and values most dear to her. The result would be a Molly/Carrie who was no longer Carrie.

There are psychological limits to the virtues, and not all of the virtues are compatible with all of the others. Experience suggests to me that among normal adult humans - I shall have to be permitted to exclude Mother Teresa from my universalization-a high degree of autonomy is almost never found in combination with a high degree of solicitude for others. If Frey were arguing that autonomy was necessary for sainthood, I would be inclined to agree with him. In the saints, we find that rare combination of autonomy and care, but it is precisely the extraordinariness of this combination that makes such people saints. Normal adult humans like us have more difficulty putting lots of autonomy together with lots of care for others. Frey argues that autonomy is necessary for normal adult humanhood. Carrie is a counterexample. So even if we do not dismiss Frey's second imagined response as granting the point at issue, it still fails. Carrie's moral life would not necessarily be of a higher quality if she were to become autonomous.

There is a third response open to Frey; he could deny that Carrie is not autonomous. If we dig deep enough in her story, he might say, we shall see that she really has a free will and that her desires are not determined by irresistible forces of nature or socialization. Such an argument might go as follows. Carrie has her own ideas about what the good life is for her, and she is pursuing them. She is as free as the autonomous saint who obeys God's voice because she wants to obey God's voice. Carrie may not have been autonomous in her choice of workplaces, but she is autonomous in the choice of a self-sacrificial way of life.

This response is a strong one, but its ultimate failure may be seen by considering the following conversation in which the philosopher tries to expose Carrie's allegedly hidden autonomy.
Frey: "Even though you say you are nonautonomous because you did not choose your secretarial job, you did choose to go to work, and in this you demonstrated your autonomy."

Carrie: "I did not choose to go to work outside the home; I had to work to make ends meet."

Frey: "Well, you chose that, to go to work to make ends meet, and you did it because you love your family, no?"

Carrie: "In a sense I chose it. But that choice was influenced as much by my husband's (unspoken) wish that I go to work and by my own perception of my family's needs as it was by my own interests. In fact, when I think about it, I probably would not have chosen to work had I not been very subtly coerced. So I guess I should say, no, that $I$ did not choose to work."

Frey: "But do you agree that you love your family, and that you would choose to satisfy their needs and your husband's desires above all else?"

Carrie: "Yes."

Frey: "Then when you make choices that pursue these goals you demonstrate your autonomy."

Carrie: "That sounds convincing. But isn't autonomy the control of lower order desires by higher order reflection?"

Frey: "Yes."

Carrie: "Then am I really autonomous when I 'decide' to do what I perceive my husband wants me to do and what I feel my family wants me to do? Isn't this more like 'acting under the influence of forces outside' myself than 'acting so as to make something for myself' of myself?"

Frey: "Do you think it is?"

Carrie: "Yes, I do. For religious reasons, I would rather be subject to these others' desires than to pursue my own self-interested ends independently of them. But even this way of speaking is foreign to me."

Frey: "Why?"

Carrie: "It is not very flattering to me, and it is not the way I would put things."

Frey: "How would you put them?"

Carrie: "I would not put them in a way that suggested that I once faced a stark choice between (a) acting to please my husband and family and (b) acting to please myself. Nor would I say that I deliberated about those two potential life plans and then settled on (a). That is a false picture. I never faced the choice, nor made such a decision."

Frey: "Really? Why?" 
Carrie: "Because I am naturally a person who acts on (a) without thinking much about the possibility of (b)."

Frey: "You are 'naturally' such a person? Where did you get this nature?"

Carrie: "I am naturally such a person. I got my nature from my conservative rural upbringing, from my Bleeding Heart of Jesus Catholic tradition, from my parents, from my religious subculture."

The dialogue gives us insight into a particular nonautonomous character, and adds lustre and depth to a discussion that has been pale and abstract. It shows that someone can be not only good and nonautonomous but also intelligent and nonautonomous. Nonautonomous? Certainly. Carrie no more chose her caring servant-like conception of the good life than she chose her parents.

No matter how deeply we dig beneath the layers of influence, no matter how far we go in trying to strip away the "outer" layers, we will not find a hidden autonomous self who somewhere sometime seized control of her life. That self-standing individual is not there. ${ }^{26}$ Both of these descriptions are true:

1. Carrie is good (that is, she lives a highly textured moral life), and

2. Carrie is nonautonomous (that is, she does not have control over her desires).

Because 2 is true, Carrie falls outside the line Frey has drawn. That shows the moral irrelevance of the line, not of Carrie. ${ }^{27}$

\section{Conclusion}

I started with a fable about boys drawing lines on the beach; I hope its relevance to my argument is clear. Those of us who place overweening value on autonomy make a dangerous and costly mistake. For to suggest that the value of any being's life is determined by how far that being falls from the middle of an arbitrary circle in the sand is to denigrate the lives of saintly folk like Carrie. ${ }^{28}$

I do not think that my point will be easy for everyone to see. It may be particularly difficult for those who have spent their lives talking to autonomous boys on one comer of the beach. But neither is crosscultural understanding impossible - even across very wide gaps - and to see my point we need only open our eyes, forget our prejudices, look intently at the foreign form of life, and fix our attention on particular individuals within it. Our ways of being moral may be incommensurable, but they are not impenetrable.

The problem with Frey's approach is that the moral life is so varied; no single standard should be relied upon to tell us what is normal and what is not. At best we must have a supple moral vocabulary, one equipped with a complex and diverse family of notions. Perhaps there are some lives utterly lacking in moral value, but just because they do not display autonomous control is not a good reason to begin wondering whether we may barbecue or bash them. ${ }^{29}$ Nor should we too readily ascribe universality to the central virtue of our circles. All too often this has the effect of stigmatizing other individuals and other circles as aberrant. This should no longer be acceptable, even if it is a long-established practice. Feminist, religious, and utopian communities in the West and East have ways other than Frey's for ordering and evaluating life. ${ }^{30}$ They may be less aggressively individualistic or competitive or powerconscious; they may place a higher value on interdependence or compromise or self-sacrifice. They may attach less importance to one's personal future and more importance to the collective past. But the mere fact that they do not value autonomy as highly as Frey and his boys do is no argument that they are therefore less admirable morally.

What Frey has left unsaid-what falls into the margins rather than the lines of his text-is the figure of his other, the background character out of whom Frey's autonomous self has emerged. This other, the independent agent's "mother," as it were, is the servant, the patient, the one who is subject to forces beyond her control. Such forces are powerfully displayed in the birthing process required to bring every potentially autonomous person into the world. The mother often suffers as the child establishes the necessary distance from her. But for the child then to turn around and accuse the other of moral inferiority associated with "servility" and "weakness" is to be more than ungrateful. It is culpable misinterpretation, using a single standard-a son's independence - to try to measure the value of a mother's form of labor. ${ }^{31}$

What does Carrie have to do with animals? She is a vivid reminder of how different we humans are from each other, of how difficult it is to categorize our kite flying, castle building, ice cream eating carnival using 
simple schemes like "in" and "out." If our fluid relationships with each other do not yield to such simplistic categories, how much more ill-suited such categories must be for describing the complex web of our relations to animals.

Philosophers have long sought to find a single characteristic the possession of which would set us clearly above other animals. Previously we have tried to draw the line at the possession of a soul, or at sentience, or purposiveness, or desire, belief, linguistic competence, imagination, a concept of the self, rationality, a sense of the future, or possession of moral rights. All of these lines fail because we have such different ways of living good lives, as Carrie plainly shows. There is no reason to think we may kill and barbecue Carrie just because she lacks autonomy. Nor is there any reason to think we may kill and barbecue cows and pigs just because they lack autonomy. ${ }^{32}$

Research for the article was supported by a Faculty Improvement Leave from Iowa State University during 1989-1990.

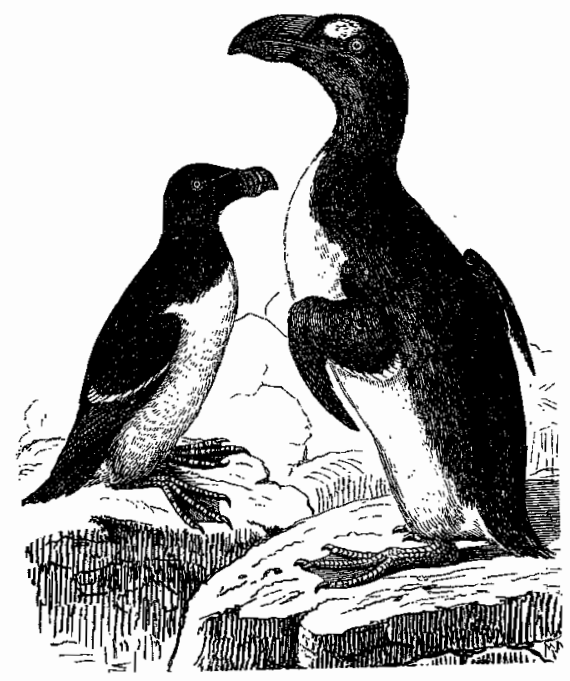

\section{Notes}

${ }^{1}$ Frey holds that if the possession of moral rights entitles one to membership in the moral circle then animals will have to be excluded, as will those humans he and we clumsily call "marginal." Marginal humans who lack language, beliefs, and interests lack the equipment necessary for possessing the right to life. Severely handicapped newborns, very severely mentally enfeebled adults, those in persistent vegetative states, the irreversibly comatose: all will appear-with whales, cows, and pigs--on the wrong side of the line. By Frey's reckoning, all of these beings lack the equipment necessary for the possession of moral rights: language, beliefs, and interests in the relevant sense. If they lack the necessary equipment they cannot have moral rights. It follows that in killing such beings we do not fail to respect their right to life.

The argument is predicated on the supposition that possession of moral rights is necessary for inclusion in the circle. Frey rejects the premise. See Interests and Rights: The Case Against Animals (Oxford: Clarendon Press, 1980), especially chapters 2 and 3 . Frey takes the phrase "marginal cases" from Jan Narveson, "Animal Rights," Canadian Journal of Philosophy 7 (1977): 167.

${ }^{2}$ For his arguments against the acceptability of the notion of moral rights, see Interests, pp. 7-17, and Part III (pp. 43-98) of Rights, Killing and Suffering: Moral Vegetarianism and Applied Ethics (Oxford: Basil Blackwell, 1983). For his concessions about the usefulness of the notion, see ch. 9 of Rights, "Rights, Their Nature, and the Problem of Strength," pp. 67-82.

${ }^{3}$ The Monist 70 (January 1987): 49-63. See, too, the series of articles that he describes as forthcoming (and which I have not read) for which he gives the following bibliographical references: "Autonomy and Animals," in M. Daly, A. George, eds., Animals in Society: Rights and Wrongs; "Autonomy, Proxy Agency, and Valuable Lives," in Philosophica; and "Conceptions of the Good Life and the Value of a Life," in T. Attig, D. Callan, L. W. Sumner, eds., Values and Moral Standing. Frey has apparently spent enough energy trying to erase the line drawn by rights-based approaches to the treatment of animals. The phrase "moral rights" hardly appears in the recent article, having been replaced by talk about the "value of life," while talk about the "interests" of beings has been replaced by discussions of their relative "autonomy."

\footnotetext{
${ }^{4}$ Frey uses the phrase "normal adult humans" in his first
} sentence. "Autonomy." p. 50.

5 "Autonomy," p. 50. It is worth noticing that the concept of moral rights is also central to the theories he identifies.

${ }^{6}$ Regan, The Case for Animal Rights (Berkeley: University of California Press, 1983), pp. 84-85. Cited in Frey, p. 60. 
${ }^{7}$ Frey, p. 51.

8 "Autonomy," p. 53.

9 “Autonomy," p. 53.

10 “Autonomy," p. 54.

${ }^{11}$ Frey writes: "But I do not regard all human life as of equal value; I do not accept that a very severely mentallyenfeebled human or an elderly human fully in the grip of senile dementia or an infant born with only half a brain has a life whose value is equal to that of normal, adult humans. The quality of human life can plummet ... . As the quality of human life falls, trade-offs between it and other things we value become possible ..." "Autonomy," p. 58.

Two points should be made here. First, from the premise that the quality of some people's moral lives is better than others it does not follow that the value of some people's lives is greater than others. As Paul Taylor argues, beings with (what Taylor calls) "inherent moral worth" have it equally, even though the richness and texture of their lives differs. Second, in order to account for the fact that different kinds of beings live different kinds of lives and require different forms of respectful treatment from us it is not necessary to say that the lives of some of us are greater than those of others. The twenty year old Downs syndrome patient should be treated more paternalistically than the fully conscious autonomous philosopher, but the difference in treatment does not entail nor require the postulation of a difference in their respective inherent moral worth. Cf. Taylor's Respect for Nature: $A$ Theory of Environmenlal Ethics (Princeton: Princelon University Press, 1986).

Ned Hettinger has patiently explained this point to me. The relevant distinction is between moral considerability or moral standing (which a being either has or does not have) and that of the moral quality of a being's life (which comes in degrees and may be graded or ranked). Any being with moral considerability has it fully, even if his life is wasting away because of Alzheimer's disease. Clearly, even on this hierarchical view of better and worse moral lives, a being's being located at the bottom of the scale is in itself no reason to think that that being may be disrespectfully treated, much less killed, eaten, deprived of a family life, or had chemicals poured in its eyes.

${ }^{12}$ How many people in the world are like Carrie? I am currently reading two realistic novels, Louise Erdrich's The Beet Queen (New York: Henry Holt, 1986), and Iris Murdoch's The Philosopher's Pupil (New York: Viking, 1983). Out of a total of roughly twenty major characters in these two contemporary works, I would call all twenty "normal adult humans," roughly fifteen of them morally admirable people, but only five of them autonomous in Frey's sense. This seems a representative assessment of my nonfictional acquaintances as well. If the novels are at all representative then, roughly seventy-five percent of all people are morally good, but only a third of those exercise Frey"s "autonomy as control." If there are five billion people in the world, this would mean that some two billion are nonautonomous and lead lives of a high moral quality.

${ }^{13}$ In "The Value of Autonomy," The Philosophical Quarterly 32 (January 1982): 3544 , Robert Young raises the question of whether autonomy is always a virtue. The major problem Young sees is that of the tyrant who uses his or her autonomy to devise evil schemes. As will become clear, this is not my primary objection to the concept. Young touches on my concern, however, in his conclusion: “... what I have said ... does not imply that the exercise of an individual's autonomy may not at the same time introduce more disvalue than the value that resides in that autonomy" (p. 44).

14 “"Autonomy," p. 57.

15 “Autonomy," p. 57.

${ }^{16}$ The quotation is from Regan's paper, "The Case for Animal Rights," in Peter Singer, ed., In Defence of Animals (Oxford: Blackwell, 1985), p. 22. Quoted in Frey, "Autonomy,"p. 59.

17 "Preservative Love and Military Destruction: Reflections on Mothering and Peace," in Mothering: Essays in Feminist Theory, ed. Joyce Trebilcot (Totowa: Rowman \& Allenheld, 1984), p. 253. Quoted in Card, "Women's Voices,"pp. 133-134.

${ }^{18}$ Ruddick, p. 253. Quoted in Claudia Card, “Women's Voices and Ethical Ideals: Must we Mean What We Say?" Ethics 99 (October 1988): 134.

${ }^{19}$ (London: The Women's Press, 1979), p. 59. Quoted in Jean Grimshaw, Philosophy and Feminist Thinking, p. 139.

${ }^{20}$ Carrie regards the deliberate pursuit of her own ends independently of the needs and ends of others as something she ought not to do. Perhaps this is because she believes that such self-interested reflection is sin. Perhaps she thinks that it will distract her energies from her children (with whom she deeply identifies herself). Perhaps she believes as the British novelist Charles Williams did, that some people have the gift and responsibility of carrying psychological and spiritual burdens for others. Perhaps Carrie believes as Williams and Saint Paul did, that her life is not her own to control. "He and we co-inhere," Williams wrote, and the New Testament puts it even more mysteriously: "I live: yet not I but Christ liveth in me." Whatever the explanation, Carrie's hesitance to pursue her own independence is not unprecedented. For a philosophical defense of Williams' doctrine of Co-Inherence, 
see Charles Talliaferro, "The Co-Inherence," Christian Scholar's Review 18 (June 1989): 333-345. The biblical quotation is from Williams, "The Way of Exchange," in The Image of the City and Other Essays, ed. Anne Ridler (Oxford: Oxford University Press, 1958). Quoted in Talliaferro, p. 334.

21 "Personal Autonomy and the Paradox of Feminine Socialization," The Journal of Philosophy 84 (November 1987): 619-628. Meyers points out that "feminists are justifiably suspicious of the professed fulfillment of many traditional women. Since traditional women do not use autonomy skills adeptly, there is no reason to believe that they are doing what they really want to do" (p. 628). To her credit, Meyers goes on to point out that "Conversely, however, if an adult who has been raised to assume the tasks of housekeeping and parenting embraces this role, feminists would have no grounds for complaint provided that the individual is skilled in autonomy competency" (p, 628).

Meyers is too enamored of autonomy. As Kathryn Pyne Addelson points out in a response to the article, Meyers' liberal approach to the lives of traditional women does not, in the end, "respect the worlds and lives of many men, women, and children, and they leave many of our own secular, white, professional biases unexamined .... The fundamentalist mother is faulted for accepting creationism uncritically, but we do not ask about the schoolteachers' acceptance of Darwinevolutionary theory is true, is it not?" Addelson concludes that "in one form or another, the specter of elitism re-emerges" in Meyers' feminism. I agree. "Autonomy and Respect," The Journal of Philosophy 84 (November 1987): 629.

${ }^{22}$ In what follows, I am drawing on some ideas of Harry Frankfurt's, and a suggestion of Phil Quinn's.

${ }^{23}$ Harry Frankfurt, The Importance of What We Care About (Cambridge: Cambridge University Press, 1988), p. 21.

24 Meyers, p. 621.

${ }^{25}$ Nietzsche held that every person who fills the role of a servant is necessarily self-deceived and pitiable. I have tried to suggest why this judgment does not apply to Carrie. She has lived her life tending to the needs and desires and welfares of others: of her children, her husband, her employers, her brothers and sisters, their children, her neighbors, but she has not done so in an unreflective or grudging way. She has not "taken control" of her life or asserted her right to pursue her own ends "free of the coercive interference of others," but she is aware that she could do so. She flourishes with a conception of the good life she inherited.

${ }^{26}$ The language itself requires us to postulate what is not there; Descartes' unified subject reading life-options from a menu and choosing number 23 over number 11 . As feminists from Carol Gilligan to Marilyn Friedman have argued, the paradigm is too individualistic to capture the most important elements of many women's (and men's!) moral experiences. Cf. Gilligan's In a Different Voice: Psychological Theory and Women's Development (Cambridge: Harvard University Press, 1982), and Friedman's "Autonomy and the Split-Level Self," Southern Journal of Philosophy 24 (1986): 19-35.

${ }^{27}$ Frey could also argue that Carrie's heteronomous lifeshowing care for the needs of others at the potential cost of her own independence-is irrational. I cannot here do justice to this objection, but it is worth pointing out in passing that a number of very rational people have recently come to the defense of at least one nonautonomous form of ethics, the Divine Command theory. If we assume that philosophers who write in mainstream analytic philosophy journals are not likely to propose irrational ideas, then the recent proliferation of philosophical defenses of this theological ethic provides us with some reason not to think that "ethics" is impossible without autonomy as a central pillar. See, for example, Philip L. Quinn, Divine Commands and Moral Requirements (Oxford: Clarendon Press, 1978); Robert Merrihew Adams, "A Modified Divine Command Theory of Ethical Wrongness," in Gene Outka and John P. Reeder, Jr., eds., Religion and Morality (Garden City: Anchor Press, 1973); and "Autonomy and Theological Ethics," and "Divine Command Metaethics Modified Again," both reprinted in Adams, The Virtue of Faith and Other Essays in Philosophical Theology (New York: Oxford, 1987), pp. 123-127 and 128-143; Baruch A. Brody, "Morality and Religion Reconsidered," in Brody, ed., Readings in the Philosophy of Religion: AnAnalytic Approach (Englewood Cliffs: Prentice-Hall, 1974): 592-603; Janine Marie Idziak, "In Search of 'Good Positive Reasons' for an Ethics of Divine Commands: A Catalogue of Arguments," Faith and Philosophy 6 (January 1989): 47-64.

${ }^{28}$ Since moral circles and the standards of judging the good intemal to them are various, it is best to accord each human being the same kind of inherent value we attribute to ourselves. This is the central insight of Frey's utilitarian tradition, that each counts for one and only for one. Because we lack a consensus on how to measure the richness of moral life, we ought not to make the quality of moral life the basis for deciding how to treat one another. We ought to act as if each of us possessed equal value, respecting others as if they were ends and never means unless we have good reasons for thinking that something is not an end.

${ }^{29}$ Further, making such a judgment is so momentous that we probably should not even tempt ourselves with it unless forced to do so. As Alan Donagan points out in The Theory of Morality (Chicago: University of Chicago Press, 1981), the capacity of westem industrialized nations to support even the most vulnerable of humans is great. Until we are so poor and resourceless that we must begin killing some humans we ought not to worry about drawing lines. 
${ }^{30}$ Where did the idea get started that autonomy is a moral idea which all rational persons ought to pursue and a constitutive feature of normal adult human life? Perhaps it was on an island, where controlling the boats that arrived on and departed from one's shores was essential for survival. If exercising control over one's watery boundaries means the difference between life and death, then control will become an important feature of that form of life. It is also likely that certain habits will be encouraged, habits like disciplining one's thoughts and emotions, pursuing one's interests, deliberately formulating a plan of life, and sticking to it. But "control" may come at the cost of other habits, such as "release," including the capacity to express emotion, sacrifice one's own desires, put the physical and spiritual needs of the vulnerable above one's own. Informal observation of the world tells me that the first set of traits is typically found in certain individuals (e.g., male anglophile academics), and not in others (e.g., female conservative Christians), and more commonly found in certain communities (e.g., secular institutions of higher learning in western Europe and North America), and not in others (e.g., loosely-knit networks of Iranian women friends). This is not surprising, of course. The first set of virtues are those conducive to the sustenance of certain forms of life, and the second set are those conducive to the sustenance of other forms of life. We should not fault one for not being the other.

${ }^{31}$ It is also to employ the sort of gendered language feminists have taught us to recognize as rhetorical in the worst sense. It is the worst because it sounds benign even as it carries powerful political import. Its use has long been the most subtle and effective tool with which one group (often composed primarily but not exclusively of men) has, wittingly or unwittingly, marginalized the moral experiences and languages of other groups (often composed largely but not exclusively of women). To continue to pursue such ways of speaking is not profitable for those of us trying to listen "with a different ear" to "the different voices" not only of women but also of all those historically excluded from the moral philosophers' games. I take the phrases from Gilligan and Claudia Card, the latter of whom has written that "It is important to listen to women with a different ear, not simply to listen for a different voice in women." Card, "Women's Voices,"p. 134.

\footnotetext{
${ }^{32}$ In addition to the commentators whose responses follow, I have profited from the criticisms of Ned Hettinger, Peter List, Phil Quinn, Richard Noland, and Harry Frankfurt. I discussed the paper with colleagues in the Philosophy Departments at Oregon State University and Western Illinois University; read it at the Society for the Study of Ethics and Animals at the 1990 Pacific Division Meeting; and read it again at a conference on animal rights at San Francisco State University in April, 1990.
}

\section{Response: Comstock on Autonomy

\author{
Leslie P. Francis \\ University of Utah
}

There are many things to say about Comstock's paper. I want to comment on two issues: the role of "line drawing about autonomy" in the discussion of our treatment of animals and the conclusion that fuller autonomy might decrease the moral quality of the life of a caring woman such as Carrie.

Comstock's basic point is that "autonomy is virtually useless as a line telling us which beings have and which beings do not have moral standing." The bulk of his paper is devoted to an argument that autonomy is not always part of a good life for human beings, aimed to show that a line drawn in terms of autonomy between humans and nonhumans is at best very fuzzy. But what is the relevance of this strategy to conclusions we might draw about our treatment of animals?

Comstock's strategy is directed to an argument for differential treatment of humans and nonhumans which goes like this. Defenders of the differential treatment of humans and nonhumans rely on showing that humans and nonhumans have different moral statuses. One method of showing this different status is to attribute a property to humans that nonhumans lack. Autonomy is the property used by Frey to draw this line. But if the line cannot be drawn, because autonomy is not of value to all humans, then we cannot show that humans and nonhumans have different moral statuses and thus that it is permissible to treat them differently.

But there are crucial gaps in Comstock's strategy. First, even if we grant that increased autonomy would not be good for all humans, it does not follow that autonomy is irrelevant to how we ought to treat them. Second, there are many ways to defend differential

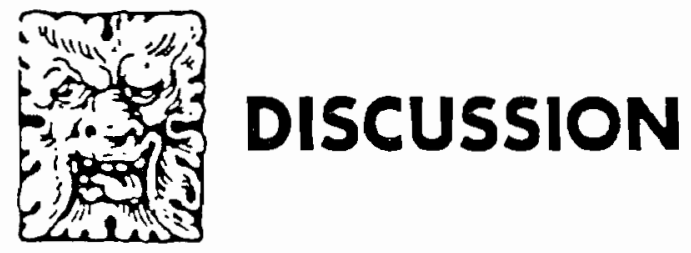

